\title{
PENGARUH EKSPEKTASI PELANGGAN (HARAPAN PELANGGAN) DAN KEPUASAN PELANGGAN TERHADAP LOYALITAS PELANGGAN INTERNET (STUDI KASUS PADA PELANGGAN INTERNET PT. TELKOM CABANG BIMA)
}

\author{
Nurfajriani \\ Sekolah Tinggi Ilmu Ekonomi (STIE) Bima \\ nurfajriani.16stiebima@gmail.com
}

\begin{abstract}
Abstrak. Jumlah pemakai internet di indonesia semakin meningkat. Saat ini manfaat menggunakan internet sangat banyak dirasakan oleh masyarakat, terutama bagi sekelompok masyarakat yang mengganggap teknologi internet adalah sumber untuk mendapatkan berbagai informasi. Perusahaan dituntut untuk mampu mengerti apa yang menjadi harapan dari konsumen dari waktu ke waktu, terutama harapan untuk memperoleh akses internet yang berkualitas. Perusahaan harus fokus pada peningkatan pencapaian jumlah pelanggan, agar dapat menguasai persaingan di pasar. Salah satu caranya adalah dengan memberi kepuasan pada pelanggan dalam menggunakan internet yang cepat maka perusahaan akan memperoleh pelanggan yang setia dan akan menciptakan hubungan timbal balik antara pelanggan dan perusahaan. Tujuan penelitian ini adalah mengetahui dan menganalisis pengaruh ekspektasi pelanggan dan kepuasan pelanggan terhadap loyalitas pelanggan (Studi Kasus Pada Pelanggan Internet PT.Telkom Cabang Bima). Jenis penelitian yang digunakan adalah asosiatif, dengan sampel 96 responden. Teknik sampling yang digunakan adalah purposive sampling karena jumlah populasi yang tidak diketahui pasti jumlahnya (Unknown Population). Pengumpulan data penellitian dengan kuesioner yang menggunakan skala Likert. Kemudian metode analisis data memakai uji validitas, uji reliabilitas, regresi berganda, korelasi berganda, uji asumsi klasik, uji t (parsial) dan uji F (simultan). Hasil dari penelitian ini menyimpulkan bahwa ekspektasi pelanggan memiliki pengaruh signifikan terhadap loyalitas pelanggan yang dibuktikan dengan nilai uji t sebesar 2,587 dan Sig 0,011. Sedangkan kepuasan pelanggan tidak mempunyai pengaruh signifikan terhadap loyalitas pelanggan dengan nilai uji t 0,984 dan Sig 0,328. Selanjutnya ekspektasi pelanggan dan kepuasan pelanggan mempunyai pengaruh signifikan terhadap loyalitas pelanggan secara simultan dengan nilai uji F sebesar 4,470 dan Sig 0,014.
\end{abstract}

Kata kunci: : Ekspektasi Pelanggan, Kepuasan Pelanggan, Loyalitas Pelanggan

\section{PENDAHULUAN}

Pengguna internet di indonesia dari waktu ke waktu semakin meningkat. Manfaat menggunakan internet sangat banyak dirasakan oleh masyarakat, terutama bagi sekelompok masyarakat yang mengganggap teknologi internet adalah sumber untuk mendapatkan berbagai informasi. Dari aktifitas penggunaan internet yang seolah tanpa batas ini dianggap dapat membentuk suatu komunitas-komunitas baru yang merupakan pengelola berbagai aplikasi berbasis internet seperti facebook, twitter. Sehingga tidak menutup kemungkinan melalui komunitas dalam internet tersebut dapat terjalin kerjasama bisnis. Karena banyaknya manfaat tersebut, maka saat ini pengguna internet di dunia semakin meningkat jumlahnya seiring dengan banyaknya kemudahan-kemudahan yang diperoleh dalam penggunaan internet.

Bagi perusahaan yang terpusat untuk mendapatkan pelanggan (customer oriented) seperti PT. Tekom Cabang Bima sangat memperhatikan kepuasan pada pelanggan yang menjadi sasaran tujuan pemasaran produknya. Pelanggan yang merasa puas akan membentuk terjadinya loyalitas 
pelanggan. Begitu pula halnya ekspektasi pelanggan diyakini berperan penting dalam menentukan kualitas suatu produk dan kepuasan pelanggan. Dalam memberikan penilaiannya, seorang pelanggan akan memakai variabel harapan yang dimilikinya sebagai pedoman dalam memilih barang maupun jasa. Oleh karena itu, bagi PT. Telkom Cabang Bima, konsumen yang memiliki loyalitas tinggi dianggap penting keberadaannya artinya selain menunjukkan besarnya keuntungan yang didapat, loyalitas pada konsumen juga menunjukan image perusahaan di mata konsumen.

Khusus di Kota Bima, PT. Telkom Cabang Bima masih menjadi market leader dalam penggunaan internet wi-fi, meskipun banyak provider lain seperti telkomsel, indosat, XL axiata dll namun masih terbatas pada penggunaan internet pada kartu di handphone. Permasalahan yang timbul adalah adanya persaingan di bisnis internet ini menjadi tantangan berat bagi PT. Telkom Cabang Bima, misalnya masih tingginya keluhan pelanggan internet pada masalah akses jaringan internet yang lambat, sehingga ekspektasi pelanggan tidak tercapai atau tidak sesuai harapan, pelanggan merasa kurang puas dengan pelayanan dan kecepatan akses internet, dan pelanggan banyak yang loyalitasnya kurang, hal ini terlihat dari banyak pelanggan yang beralih menggunakan paket internet praktis lewat kartu perdana operator seluler.

Berdasarkan uraian tersebut diatas, maka dilakukan penelitian untuk menganalisis sejauh mana ekspektasi pelanggan dan kepuasan pelanggan mempengaruhi loyalitas pelanggan. Hal tersebut menjadi latar belakang dalam melakukan penelitian dengan judul "Pengaruh Ekspektasi Pelanggan (Harapan Pelanggan) Dan Kepuasan Pelanggan Terhadap Loyalitas Pelanggan Internet (Studi Kasus Pada Pelanggan Internet PT. Telkom Cabang Bima)"

\section{Manajemen Pemasaran}

Pemasaran adalah suatu proses dan manajerial yang membuat individu atau kelompok mendapatkan apa yang mereka butuhkan dan inginkan dengan menciptakan, menawarkan dan mempertukarkan produk yang bernilai kepada pihak lain atau segala kegiatan yang menyangkut penyampaian produk atau jasa mulai dari produsen sampai konsumen.

Ada beberapa definisi mengenai pemasaran diantaranya adalah :

- Philip Kotler (Marketing) pemasaran adalah kegiatan manusia yang diarahkan untuk memenuhi kebutuhan dan keinginan melalui proses pertukaran.

- Menurut Philip Kotler dan Amstrong pemasaran adalah sebagai ssuatu proses sosial dan managerial yang membuat individu dan kelompok memperoleh apa yang mereka butuhkan dan inginkan lewat penciptaan dan pertukaran timbal balik produk dan nilai dengan orang lain.Kotler, Philip, 1997, Marketing Management Analysis, Planning, Implementation and Control, 9 th Edition, Prentice-Hall, New Jersey.

\section{Ekspektasi Pelanggan}

Menurut pendapat Zeithaml (2013:87), harapan pelanggan adalah semua hal yang menjadi keinginan atas suatu produk yang akan didapatkan sehingga terbentuk keyakinan pelanggan yang dijadikan pedoman untuk menilai hasil dari penggunaan produk tersebut. Namun dalam 
beberapa kasus sering diketahui antara harapan pelanggan dengan produk yang diinginkan belum tercapai adanya kecocokan, misalnya : sifat standar harapan yang jelas, banyaknya standar yang dipakai, serta sumber harapan yang dianggap masih jauh dari apa yang menjadi keinginan konsumen.

Indikator dari ekspektasi pelanggan adalah :1. Enduring Service Intensifiers 2. Personal Need (Kebutuhan perorangan) 3. Transitory Service Intensifiers 4. Perceived Service Alternatives 5. Self Perceived Service Role 6. Situational Factors 7. Explicit Services Promises 8. Implicit Service Promises 9. Word of Mouth (Rekomendasi) 10. Past Experience (Pengalaman masa lalu)

\section{Kepuasan Pelanggan}

Menurut pendapat Fandy Tjiptono (2015:146), kepuasan pelanggan adalah evaluasi atau penilaian yang dilakukan setelah membeli dimana dari berbagai alternatif produk yang dipilih atau dibeli setidaknya akan diperoleh hasil yang sama atau diatas rata-rata harapan pelanggan, sedangkan bila hasil yang dirasakan tidak sesuai dengan harapan maka akan muncul rasa ketidakpuasan dari pelanggan.

Dalam mengukur kepuasan pelanggan terdapat lima indikator yang dapat digunakan menurut (Tjiptono, 2015:148) yaitu : 1. Kemampuan karyawan dalam memberi pelayanaan sesuai dengan harapan 2. Daya tanggap karyawan dalam membantu konsumen sesuai dengan harapan 3. Jaminan yang diberikan dalam melayani konsumen sesuai dengan harapan 4. Empati yang diberikan kepada pelanggan sesuai dengan harapan 5. Fasilitas yang diberikan dalam melayani konsumen sesuai dengan harapan.

\section{Loyalitas Pelanggan}

Definisi loyalitas pelanggan menurut Dharmmesta dkk (2012:34) adalah komitmen pelanggan untuk bertahan pada satu produk secara berkesiambungan dari waktu ke waktu dan menjadi langganan atau membeli ulang lagi produk tersebut secara terus menerus dimasa yang akan datang, meskipun terjadi situasi yang tak terduga sehingga berpotensi mengakibatkan perubahan perilaku konsumen.

Indikator loyalitas pelanggan adalah : 1 . Pembelian ulang, 2. tidak mudah terpengaruh 3. merekomendasikan pada orang lain.

\section{METODE PENELITIAN}

\section{Objek Penelitian}

Penelitian ini dilakukan pada PT. Telkom Cabang Bima yang beralamat di Jalan Soekarno Hatta, Kelurahan Lewirato, Kecamatan Mpunda, Kota Bima, Nusa Tenggara Barat. Perusahaan ini bergerak dibidang pelayanan jasa telekomunikasi dan internet. Lamanya penelitian ini dilakukan dalam dua bulan yaitu dari bulan januari 2020 sampai bulan februari 2020.

\section{Metode dan Teknik Pengumpulan Data}

Dalam penelitian ini menggunakan metode pengumpulan data primer yaitu data yang diperoleh secara langsung dari lokasi/objek penelitian.

Teknik Pengumpulan data dilakukan dengan cara :

a. Kuisioner merupakan teknik pengumpulan data dengan cara penyebaran angket yang berisi sejumlah pernyataan, dimana setiap jawaban dari pertanyaan tersebut memiliki bobot nilai yang berbeda.

b. Wawancara merupakan Wawancara digunakan sebagai teknik pengumpilan 
data apabila peneliti ingin melakukan studi pendahuluan untuk mengemukakan permasalahan yang harus diteliti, dan juga apabila peneliti ingin mengetahui hal-hal dari responden yang lebih mendalam dan jumlah respondennya sedikit atau kecil

c. Studi pustaka merupakan tahap yang penting dalam kegiatan penelitian yang merupakan rangkaian proses pengayaan ilmu pengetahuan. Mengingat eratnya keterkaitan antara penelitian dengan pengetahuan yang sudah ada maka dalam melakukan kegiatan penelitian, seorang peneliti harus dekat dengan perpustakaan sebagai gudang ilmu pengetahuan.

\section{Sampel dan Populasi}

Populasi yang digunakan yaitu seluruh konsumen yang menggunakan internet pada PT. Telkom Cabang Bima namun jumlahnya tidak diketahui secara pasti (unknown population).

Teknik sampling yang digunakan adalah sampling Purposive. Oleh karena itu, menurut Riduwan (2015:65), untuk menentukan jumlah sampel dalam populasi yang tidak diketahui maka digunakan rumus cochran dan dan diperoleh sampel sebanyak 96 orang.

Rumus cochran :

$$
n_{0}=\frac{z^{2} p q}{e^{2}}=\frac{(1,96)^{2}(0,5)(0,5)}{(0,1)^{2}}=
$$

96 orang

Keterangan :

$\mathrm{n}_{0}=$ Ukuran sampel $\mathrm{z}^{2}=$ abscissa kurva normal yang memotong area sisi (tails), atau 1tingkat kepercayaan, misalnya sebesar $95 \%$

$\mathrm{e}^{2}=$ tingkat kepercayaan yang diinginkan

$\mathrm{p}=$ proporsi yang diestimasi suatu atribut yang ada dalam suatu populasi

$\mathrm{q}=1-\mathrm{p}$

\section{Metode Analisis Data}

Dalam penelitian ini menggunakan metode analisis kuantitatif yaitu data yang dapat dihitung atau diukur dengan angka, dalam hal ini data tentang ekspektasi pelanggan, kepuasan pelanggan dan loyalitas pelanggan. Selanjutnya dilakukan analisis dengan tahapan-tahapan sebagai berikut :

1. Uji Validitas adalah pengujiaan yang dilakukan untuk mengukur sejauh mana ketepatan dan kecermatan alat ukur ketika melakukan fungsi ukurnya (Azwar, 2016: 56). Syarat untuk dianggap valid adalah kalau $r=0,300$ atau lebih.

2. Uji reliabilitas adalah suatu pengujian yang dilakukan untuk mengetahui apakah item-item penyataan dapat dipercaya keakuratannya atau tidak. Syarat untuk menyatakan bahwa butir instrument dinyatakan reliabel apabila nilai Cronbach's Alfa sama dengan atau lebih besar dari 0,6 (Cronbach's Alfa $\geq 0,6$ ) (Azwar, 2016: 83).

3. Uji asumsi klasik adalah suatu pendekatan analisis yang dilakukan dalam menilai apakah di dalam sebuah model regresi linear Ordinary Least Square (OLS) terdapat masalahmasalah yang berkaitan dengan 


asumsi klasik. Uji asumsi klasik terdiri
dari uji normalitas

4. Regresi linier berganda menurut Sugiyono (2016 : 224) adalah hubungan fungsional ataupun kausal antara dua atau lebih variabel bebas dengan satu variabel terikat.

5. Koefisien korelasi berganda adalah angka yang menunjukkan arah dan kuatnya pengaruh atau hubungan antara dua atau lebih variabel bebas dengan satu variabel terikat. (Sugiyono, $2016: 230$ )

6. Uji $\mathrm{t}$ adalah pengujian statistik yang dilakukan untuk mengetahui signifikansi pengaruh secara parsial (Sugiyono, 2016 :236)

7. Uji F yaitu uji statistik untuk mengetahui signifikansi pengaruh dua atau lebih variabel bebas secara bersama-sama terhadap variabel terikat dan atau untuk menguji apakah model regresi yang dibuat signifikan atau tidak signifikan.

\section{HASIL DAN PEMBAHASAN}

Uji Validitas

Tabel 1. Hasil Uji Validitas

\begin{tabular}{|c|c|c|c|c|c|c|c|}
\hline Jji Validitas & & & & Variabel & $\begin{array}{c}\text { Cronbach's } \\
\text { alpha }\end{array}$ & Standar & Ket \\
\hline \multicolumn{4}{|c|}{ Tabel 1. Hasil Uji Validitas } & Ekspektasi & 0,802 & 0,6 & Reliabel \\
\hline Variabel & Pernyataan & $\mathbf{r}_{\text {hitung }}$ & $\mathbf{r t}_{\text {abel }}$ & Ket pelanggan & & & \\
\hline Ekspektasi & Item 1 & 0,388 & 0,300 & Valid $_{\text {Kepuasan }}$ & 0.793 & 0.6 & Reliabel \\
\hline Pelanggan & Item 2 & 0,392 & 0,300 & Valid pelanosan & & & \\
\hline & Item 3 & 0,312 & 0,300 & Valid & & & \\
\hline & Item 4 & 0,330 & 0,300 & ValidLoyalitas & 0,489 & 0,6 & Reliabel \\
\hline & Item 5 & 0,455 & 0,300 & Validpelanggan & & & \\
\hline & Item 6 & 0,313 & 0,300 & Valid & & & \\
\hline & Item 7 & 0,588 & 0,300 & Sumper : Data I & er Diolah, 2 & & \\
\hline & Item 8 & 0,388 & 0,300 & Valid & & & \\
\hline & Item 9 & 0,351 & 0,300 & Valldasil uji reli & itas terhadap & m perny: & \\
\hline & Item 10 & 0,339 & 0,300 & paldid variabel & ektasi pelar & an, kepu & \\
\hline & Item 11 & 0,389 & 0,300 & valid ogan da & lovalitas & Iggan & \\
\hline & Item 12 & 0,662 & 0,300 & Realidggan & loyantas & lggan c & \\
\hline & Item 13 & 0,392 & 0,300 & dinjyatakan reli & 1. Karena & cronbc & \\
\hline & Item 14 & 0,660 & 0,300 & Nlapila yang did & t sudah me & ai atau & \\
\hline & Item 15 & 0,547 & 0,300 & dalidstandar yan & itetapkan ya & 0,6 . & \\
\hline & Item 16 & 0,344 & 0,300 & Valid & & & \\
\hline & Item 17 & 0,680 & 0,300 & Vadidtormalit: & & & \\
\hline & Item 18 & 0,369 & 0,300 & Valid & & & \\
\hline
\end{tabular}

Tabel 2. Hasil Uji Reliabilitas 
Pengujian kenormalan terrhadap residual regresi dua variabel bebas terhadap variabel

One-Sample Kolmogorov-Smirnov Test

\begin{tabular}{|c|c|c|}
\hline & & $\begin{array}{c}\text { Unsta } \\
\text { ndard } \\
\text { ized } \\
\text { Predi } \\
\text { cted } \\
\text { Value }\end{array}$ \\
\hline $\mathrm{N}$ & & 96 \\
\hline Normal Parameters ${ }^{\mathrm{a}}$ & Mean & $\begin{array}{r}25.53 \\
1250 \\
0\end{array}$ \\
\hline & $\begin{array}{l}\text { Std. } \\
\text { Deviat } \\
\text { ion }\end{array}$ & $\begin{array}{r}.5434 \\
0670\end{array}$ \\
\hline Most Extreme Differences & $\begin{array}{l}\text { Absol } \\
\text { ute } \\
\text { Positiv } \\
\text { e }\end{array}$ & $\begin{array}{l}.075 \\
.075\end{array}$ \\
\hline & $\begin{array}{l}\text { Negati } \\
\text { ve }\end{array}$ & -.052 \\
\hline Kolmogorov-Smirnov Z & & .731 \\
\hline Asymp. Sig. (2-tailed) & & .660 \\
\hline
\end{tabular}

Berdasarkan tabel diatas diperoleh nilai Asympari hasil uji SPSS ditemukan bahwa Sig. (2-tailed) sebesar 0,660 dan nilai ini lebih bessar dalam penelitian tidak terjadi dari $0,05(0,660>0,05)$ artinya data pada penelitjann ini berdistrbusi normal.

Sesuai syarat dan ketentuan, dimana : Jika nilai Asymp. Sig. $(2-$ tailed $) \geq 0,05$ maka data berdistribusi normal. Jika nilai Asymp. Sig. $(2$ - tailed $)<0,05$ maka data tidak berdistribusi normal.

\section{Uji Multikolinearitas}

Ketentuan :

Tolerance value $<0,10$ atau VIF $>10$ maka terjadi multikolenearitas

Tolerance value $>0,10$ atau $\mathrm{VIF}<10$ maka tidak terjadi multikolenearitas terikat dapat dilihat pada tabel One-Sample Kolmogogrov-Smirnov Test berikut ini

Coefficients $^{\mathrm{a}}$

\begin{tabular}{cccc}
\hline Model & & \multicolumn{2}{c}{ Collinearity Statistics } \\
& & $\begin{array}{c}\text { Toleranc } \\
\mathrm{e}\end{array}$ & VIF \\
1 & & & \\
& & & \\
& & \\
& $\begin{array}{l}\text { Ekspektasi } \\
\text { pelanggan } \\
\text { Kepuasan } \\
\text { pelanggan }\end{array}$ &, 964 & 1,037 \\
& & & \\
\end{tabular}

a. Dependent Variable: Loyalitas pelanggan

Berdasarkan tabel diatas diperoleh nilai tolerance untuk variabel ekspektasi pelanggan dan kepuasan pelanggan sebesar $0,964>0,10$ dan VIF sebesar $1,037<10$ maka dapat disimpulkan tidak terjadi multikolinearitas

\section{Uji Heteroskedastisitas} scatterplot dimana sebaran titik-titik tidak membentuk pola tertentu. Sehingga data dapat dikatakan tidak terjadi heteroskedastisitas.

Hal tersebut dapat dilihat pada gambar scatter plot berikut :

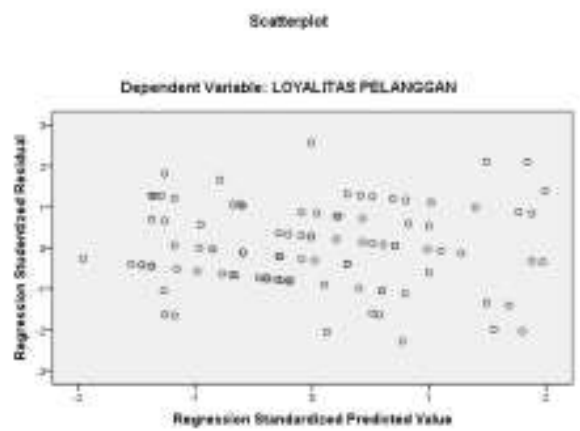




\section{Uji Autokorelasi}

Untuk uji autokorelasi digunakan Uji Durbin Watson yang hanya digunakan untuk autokorelasi tingkat satu dan mensyaratkan adanya intersep dalam model regresi dan tidak ada variabel lagi diantara variabel penjelas.

Di dalam uji Durbin Watson ini, harus memenuhi kriteria sebagai berikut :

\begin{tabular}{cc}
\hline $\begin{array}{c}\text { Kriteria Durbin } \\
\text { Watson } \\
\mathbf{1 , 6 5}<\text { DW }<\mathbf{2 , 3 5}\end{array}$ & Keterangan \\
& $\begin{array}{c}\text { Tidak terjadi } \\
\text { autokorelasi }\end{array}$ \\
$\mathbf{1 , 2 1}<$ DW $<\mathbf{1 , 6 5}$ & Tidak dapat disimpulkan \\
$\mathbf{2 , 3 5}<$ DW $<\mathbf{2 , 7 9}$ & Tidak dapat disimpulkan \\
$\mathbf{D W}<\mathbf{1 , 2 1}$ & Terjadi autokorelasi \\
DW $>\mathbf{2 , 7 9}$ & Terjadi autokorelasi \\
\hline
\end{tabular}

Sumber : Sulaiman, 2004:89

Dari hasil olah data SPSS maka diperoleh nilai durbin watson sebesar 2,044. Nilai Durbin Watson ini memenuhi kriteria $1,65<\mathrm{DW}<2,35$ yang artinya tidak terjadi autokorelasi.

\section{$1,65<2,044<2,35$}

Untuk lebih jelasnya nilai Durbin Watson dapat dilihat dari tabel olah data SPSS berikut :

\begin{tabular}{cc}
\multicolumn{2}{c}{ Model Summary $^{\mathbf{b}}$} \\
\hline Model & Durbin-Watson \\
1 & 2,044 \\
\hline
\end{tabular}

a. Predictors: (Constant), Kualitas pelayanan,

Kualitas produk

b. Dependent Variable: Loyalitas konsumen

\section{Regresi Linier Berganda}

Coefficients $^{\mathrm{a}}$

\begin{tabular}{llcc} 
Model & & \multicolumn{2}{c}{$\begin{array}{c}\text { Unstandardized } \\
\text { Coefficients }\end{array}$} \\
& B & $\begin{array}{c}\text { Std. } \\
\text { Error }\end{array}$ \\
& & & \\
& & 13,766 & 3,975 \\
& (Constant) &, 106 &, 041 \\
& Ekspektasi pelanggan &, 056 &, 057 \\
\hline
\end{tabular}

a. Dependent Variable: Loyalitas pelanggan

Dari hasil olah data diatas dengan SPSS maka dapat dimasukkan dalam persamaan regresi linier berganda sebagai berikut :

$\mathbf{Y}=\mathbf{a}+\mathbf{b} 1 \mathbf{X} 1+\mathbf{b} 2 \mathrm{X} 2$

$Y=13,766+0,106 X 1+0,056 X 2$

Dari persamaan regresi berganda tersebut dapat dijelaskan bahwa :

$\mathrm{Y}=$ nilai yang diprediksikan yaitu variabel loyalitas pelanggan

$\mathrm{a}=$ Konstanta atau bila harga $\mathrm{X} 1$ dan $\mathrm{X} 2=0$ maka nilai variabel loyalitas pelanggan adalah sebesar 13,766

b1 = koefisien regresi ekspektasi pelanggan, bila dinaikkan sebesar 1 kriteria maka loyalitas konsumen akan mengalami kenaikan sebesar 0,106

b2 = koefisien regresi kepuasan pelanggan, bila dinaikkan sebesar 1 kriteria maka loyalitas konsumen akan mengalami kenaikan sebesar 0,056

$\mathrm{X} 1$ = Variabel ekspektasi pelanggan $\mathrm{X} 2$ = Variabel kepuasan pelanggan

Korelasi Berganda

Dari hasil olah data SPSS maka diperoleh nilai untuk korelasi berganda sebesar 0,296. 


\begin{tabular}{|c|c|c|c|c|}
\hline & \multicolumn{4}{|c|}{ Model Summary } \\
\hline $\begin{array}{l}\text { Mo } \\
\text { del }\end{array}$ & $\mathrm{R}$ & $\begin{array}{c}\mathrm{R} \\
\text { Squa } \\
\text { re }\end{array}$ & $\begin{array}{l}\text { Adjuste } \\
\text { d R } \\
\text { Square }\end{array}$ & $\begin{array}{l}\text { Std. Error } \\
\text { of the } \\
\text { Estimate }\end{array}$ \\
\hline 1 & $\begin{array}{r}, 29 \\
6^{\mathrm{a}}\end{array}$ & ,088 & ,068 & 1,77150 \\
\hline
\end{tabular}

a. Predictors: (Constant), kepuasan pelanggan, Ekspekasi pelanggan

b. Dependent Variable: Loyalitas pelanggan

Untuk dapat memberi interpretasi terhadap kuatnya pengaruh itu maka dapat digunakan pedoman seperti tabel berikut:

\begin{tabular}{cc}
\hline Interval Koofisien & Tingkat Pengaruh \\
\hline $0,00-0,199$ & Sangat Rendah \\
$0,20-0,399$ & Rendah \\
$0,40-0,599$ & Sedang \\
$0,60-0,799$ & Kuat \\
$0,80-1,000$ & Sangat Kuat
\end{tabular}

Sumber : Sugiyono 2016

Jadi pengaruh kualitas produk dan kualitas pelayanan terhadap loyalitas konsumen sebesar 0,296 berada pada interval 0,20-0,399 dengan tingkat pegaruh rendah.

\section{Uji t (parsial)}

\section{Coefficients $^{\mathrm{a}}$}

\begin{tabular}{llcc}
\hline Model & & $\mathrm{t}$ & Sig. \\
\hline 1 & (Constant) & 3,463 &, 001 \\
& $\begin{array}{l}\text { Ekspektasi } \\
\text { pelanggan } \\
\text { Kepuasan } \\
\text { pelanggan }\end{array}$ & 2,587 &, 011 \\
&, 984 &, 328 \\
\hline
\end{tabular}

a. Dependent Variable: Loyalitas pelanggan

Berdasarkan hasil output SPSS diatas maka diperoleh nilai uji $\mathrm{t}$ hitung untuk variabel kualitas produk sebesar 2,587 dan nilai $\mathrm{t}$ hitung untuk variabel kualitas pextulbanan diperoleh sebesar 0,984 .

inSelanjutnya nilai $t$ hitung tersebut dhatsdingkan dengan nilai $t$ tabel untuk domn-2 =96-2 = 94 dan taraf kesalahan 5\% B.9HA diperoleh nilai $t$ tabel sebesar 1,985, dengan ketentuan bila thitung $<\mathrm{t}$ tabel maka $\mathrm{H}_{0}$ diterima dan $\mathrm{H}_{\mathrm{a}}$ ditolak begitu pula sebaliknya. Kemudian apabila nilai sig < 0,05 maka dinyatakan pengaruhnya signifikan ataupun sebaliknya.

\section{Hipotesis pertama:}

$\mathrm{Ho}_{1} ; \beta_{1}=0$, tidak terdapat pengaruh ekspektasi pelanggan terhadap loyalitas pelanggan (Studi Kasus Pada Pelanggan Internet PT.Telkom Cabang Bima).

$\mathrm{H}_{\mathrm{a} 1} ; \beta_{1} \neq 0$, terdapat pengaruh ekspektasi pelanggan terhadap loyalitas pelanggan (Studi Kasus Pada Pelanggan Internet PT.Telkom Cabang Bima).

Jadi nilai $t$ hitung untuk variabel ekspektasi pelanggan (X1) sebesar 2,587 lebih besar dari t tabel 1,985 $(2,587>1,985)$ dan nilai Sig < 0,05 $(0,011<0,05)$ artinya signifikan maka $\mathbf{H}_{\mathbf{a}}$ diterima dan $\mathbf{H}_{0}$ ditolak atau dengan kata lain hipotesis alternatif yang berbunyi terdapat pengaruh ekspektasi pelanggan terhadap loyalitas pelanggan (Studi Kasus Pada Pelanggan Internet PT.Telkom Cabang Bima) dapat diterima.

\section{Hipotesis kedua :}

$\mathrm{Ho}_{2} ; \beta_{2}=0$, tidak terdapat pengaruh kepuasan pelanggan terhadap loyalitas pelanggan (Studi Kasus Pada Pelanggan Internet PT.Telkom Cabang Bima).

$\mathrm{H}_{\mathrm{a} 2} ; \beta_{2} \neq 0$, terdapat pengaruh kepuasan pelanggan terhadap loyalitas pelanggan (Studi Kasus Pada Pelanggan Internet PT.Telkom Cabang Bima). 
Jadi nilai $\mathrm{t}$ hitung untuk variabel kepuasan pelanggan (X2) sebesar 0,984 lebih kecil dari t tabel 1,985 $(0,984<1,985)$ dan nilai $\mathrm{Sig}>0,05(0,328>0,05)$ artinya tidak signifikan maka $\mathbf{H}_{\mathbf{a}}$ diterima dan $\mathrm{H}_{0}$ ditolak atau dengan kata lain hipotesis alternatif yang berbunyi tidak terdapat pengaruh kepuasan pelanggan terhadap loyalitas pelanggan (Studi Kasus Pada Pelanggan Internet PT.Telkom Cabang Bima) diterima.

\section{Uji F (Simultan)}

\begin{tabular}{|c|c|c|c|}
\hline Model & & $\mathrm{F}$ & Sig. \\
\hline \multirow[t]{3}{*}{1} & $\begin{array}{l}\text { Regressio } \\
n\end{array}$ & 4,470 &, $014^{\mathrm{b}}$ \\
\hline & Residual & & \\
\hline & Total & & \\
\hline
\end{tabular}

a. Dependent Variable: Loyalitas pelanggan

b. Predictors: (Constant), Kepuasan

pelanggan, Ekspektasi pelanggan

Dari hasil olah data dengan SPSS diperoleh nilai uji $\mathrm{F}$ hitung $\left(\mathrm{F}_{\mathrm{h}}\right)$ sebesar 4,470 dan nilai ini selanjutnya dibandingkan dengan $\mathrm{F}$ tabel $\left(\mathrm{F}_{\mathrm{t}}\right)$, dengan dk pembilang $=$ $\mathrm{k}=2$ dan dk penyebut $=(\mathrm{n}-\mathrm{k}-1)=96-2-1$ = 93 dan taraf kesalahan yang ditetapkan $5 \%$. Maka $F_{t}=3,09$. Dalam hal ini berlaku ketentuan, bila $F_{h}$ lebih besar dari $F_{t}\left(F_{h}>F_{t}\right)$ maka terdapat pengaruh secara simultan atau dengan kata lain $\mathbf{H}_{\mathbf{a}}$ diterima dan $\mathbf{H}_{\mathbf{0}}$ ditolak begitu pula sebaliknya.

\section{Hipotesis ketiga :}

$\mathrm{H}_{03} ; \beta_{3}=0$, tidak terdapat pengaruh ekspektassi pelanggan dan kepuasan pelanggan terhadap loyalitas pelanggan (Studi Kasus Pada Pelanggan Internet
PT.Telkom Cabang Bima) secara simultan.

$\mathrm{H}_{\mathrm{a} 3} ; \beta_{3} \neq 0$, terdapat pengaruh ekspektassi pelanggan dan kepuasan pelanggan terhadap loyalitas pelanggan (Studi Kasus Pada Pelanggan Internet PT.Telkom Cabang Bima) secara simultan.

Dari hasil SPSS diatas ternyata $F_{h}>F_{t}$ atau 4,470> 3,09 maka dapat dinyatakan bahwa pengaruh secara simultan yang diuji adalah berpengaruh dan signifikan. Hal ini menjawab dan membuktikan hipotesis alternatif $\left(\mathrm{H}_{\mathrm{a}}\right)$ pada hipotesis ketiga bahwa terdapat pengaruh ekspektassi pelanggan dan kepuasan pelanggan terhadap loyalitas pelanggan (Studi Kasus Pada Pelanggan Internet PT.Telkom Cabang Bima) secara simultan atau dengan kata lain $\mathrm{H}_{\mathrm{a}}$ diterima dan $\mathrm{H}_{0}$ ditolak.

\section{KESIMPULAN}

\section{Kesimpulan}

Dari hasil dan pembahasan yang telah diuraikan diatas maka dapat ditarik kesimpulan bahwa ekspektasi pelanggan mempunyai pengaruh signifikan terhadap loyalitas pelanggan (Studi Kasus Pada Pelanggan Internet PT.Telkom Cabang Bima), dimana nilai t hitung sebesar 2,587 lebih besar dari nilai t tabel sebesar 1,985 $(2,587>1,984)$ dengan nilai signifikansi sebesar 0,011 lebih kecil dari 0,05 $(0,011<0,05)$.

Kepuasan pelanggan tidak mempunyai pengaruh signifikan terhadap loyalitas pelanggan (Studi Kasus Pada Pelanggan Internet PT.Telkom Cabang Bima), dimana nilai t hitung sebesar 0,984 lebih kecil dari nilai $\mathrm{t}$ tabel sebesar $1,985 \quad(0,984<1,985)$ 
dengan nilai signifikansi sebesar 0,328 lebih besar dari $0,05(0,328>0,05)$.

Selanjutnya ekspektasi pelanggan dan kepuasan pelanggan mempunyai pengaruh signifikan terhadap loyalitas pelanggan (Studi Kasus Pada Pelanggan Internet PT.Telkom Cabang Bima) secara simultan, dimana nilai Fhitung sebesar 4,470 lebih besar dari nilai Ftabel sebesar 3,09 $(4,470>3,09)$ dengan signifikansi sebesar $0,014(0,014<0,05)$.

\section{Saran}

Disarankan pada PT.Telkom Cabang Bima untuk tetap memperhatikan ekspektasi pelanggan (harapan pelanggan) dengan cara memberikan mutu produk internet yang berkualitas dan pelayanan yang maksimal pada para pelanggannya sehingga pelanggan merasa puas dan pada akhirnya menjadi loyal dan tidak beralih menggunakan jasa internet yang lain.

\section{DAFTAR PUSTAKA}

Dharmmesta, et. al. 2012. Manajemen Pemasaran Analisis Perilaku Konsumen. Edisi Pertama, Yogyakarta : BPFE.

Kotler, Philip dan Keller, Kevin Lane. 2016. Marketing Management, 15th Edition. New Jersey : Pearson Education Limited.

Riduwan. 2015. Dasar-Dasar Statistika. Bandung: Alfabeta

Tjiptono, Fandi. 2015. Strategi Pemasaran. Edisi Keempat, Yogyakarta : Andi.
Zeithaml, Valerie 2013. Services Marketing: Integrating Customer Focus Across the Firm . 6th ed, Mc.Graw-Hill.

Rabiqy, Yohandes. 2017. Pengaruh Ekspektasi Pelanggan, Kualitas Produk dan Kepuasan Pelanggan Terhadap Loyalitas Pelanggan Internet Telkomsel di Banda Aceh. Jurnal Universitas Teuku Umar Meulaboh, 3 (2) : 1-11.

Wijayanti, Ratna Yulia. 2015. Pengaruh Harapan Pelanggan, Kepuasan dan Sarana Fisik Terhadap Loyalitas Pelanggan (Studi Kasus pada Usaha Jasa Warnet di Kudus). Jurnal STAIN Kudus, 2 (2) : 1-24 